\title{
Toxic metal analysis of external and internal compositions and lixiviation pattern of
}

\section{costume jewelry}

Análise de metais tóxicos na composição interna e externa e na lixiviação de bijuterias

Análisis de metales tóxicos em la composición interna y externa y la lixiviación de bisutería

Received: 08/23/2021 | Reviewed: 08/28/2021 | Accept: 08/30/2021 | Published: 09/01/2021

\author{
Mateus de Aguiar Montenegro \\ ORCID: https://orcid.org/0000-0003-1029-7162 \\ Universidade de Brasília, Brazil \\ E-mail: mdamontenegro@gmail.com \\ Romulo Coriolano Dutra \\ ORCID: https://orcid.org/0000-0002-6177-112X \\ Universidade de Brasília, Brazil \\ E-mail: romulodutrac@gmail.com \\ Guilherme Bandeira Candido Martins \\ ORCID: https://orcid.org/0000-0002-1387-9355 \\ Universidade Paulista, Brazil \\ E-mail: guilherme.martins@docente.unip.br
}

\begin{abstract}
Costume jewelry may expose skin to toxic metals due to sweat and friction, causing intoxications. An investigation was conducted over costume jewelry rings to study its behavior and verify its safety throughout their use, regarding toxic metal contamination. Qualitative and quantitative elemental analysis of the internal and external layers of the ring samples (costume jewelry) were made through X-Ray Fluorescence Spectrometry (XRF) and Inductively Coupled Plasma-Optical Emission Spectrometry (ICP-OES). The ring samples were also immerged in a synthetic sweat solution for 30 days. The lixiviated solution and post treated surfaces were analyzed by ICP-OES and Search Electron Microscopy (SEM), respectively. Metals such as $\mathrm{Cu}, \mathrm{Cd}, \mathrm{Cr}$ and $\mathrm{Ni}$ were identified in the surface composition, as well in the composition of the digested samples. The synthetic sweat eroded the rings surfaces, and metals such as $\mathrm{Cd}$ and $\mathrm{Mn}$ were lixiviated by it. The results indicate the presence and lixiviation of harmful metals that may cause health and environmental problems.
\end{abstract}

Keywords: Toxic metals; Costume jewelry; Synthetic sweat.

\section{Resumo}

O uso de bijuterias pode expor a pele a metais tóxicos em razão do suor e fricção causando intoxicações. Uma pesquisa sobre bijuterias foi conduzida a fim de estudar seus comportamentos e verificar a segurança de uso em função do tempo tendo como foco a contaminação por metais tóxicos. Foram realizadas análises qualitativas e quantitativas da composição elementar superficial e interna de anéis (bijuterias) mediante a técnica de Espectroscopia de Fluorescência de Raios-X (FXR) e Espectroscopia de Emissão Óptica com Acoplamento de Plasma Induzido (EEO-API). As amostras de anéis também foram imersas em uma solução de suor sintético por 30 dias. As soluções de lixiviação e as superfícies dos anéis pós-tratamento foram analisadas pelas técnicas de EEO-API e Microscopia Eletrônica de Varredura (MEV) respectivamente. Metais como $\mathrm{Cu}, \mathrm{Cd}, \mathrm{Cr}$ e $\mathrm{Ni}$ foram identificados na composição da superfície dos anéis assim como nas amostras digeridas. A solução de suor sintético erodiu a superfície dos anéis tratados e foi observado que metais como Cd e Mn foram lixiviados. Os resultados indicam a presença e lixiviação de metais tóxicos que podem causar problemas de saúde ou ambientais.

Palavras-chave: Metais tóxicos; Bijuterias; Suor sintético.

\section{Resumen}

El uso de bisuterías puede exponer la piel a metales tóxicos debido al sudor y la fricción que poden causar intoxicaciones. La investigación sobre la bisutería se llevó a cabo con el fin de estudiar sus comportamientos y verificar la seguridad de uso en función del tiempo centrándose en la contaminación por metales tóxicos. Los análisis cualitativos y cuantitativos de la composición elemental superficial e interna de los anillos (bisuterías) se realizaron utilizando la técnica de Espectroscopia de Fluorescencia de Rayos-X (FRX) y Espectroscopia de Emisión Óptica con Acoplamiento Inducido de Plasma (EEO-AIP). Las muestras del anillo también fueron sumergidas en una solución sintética del sudor por 30 días. Las soluciones de lixiviación y las superficies del anillo de postratamiento se analizaron mediante técnicas de EEO-AIP y Microscopía Electrónica de Barrido (MEB), respectivamente. Metales como $\mathrm{Cu}, \mathrm{Cd}, \mathrm{Cr}$ y $\mathrm{Ni}$ fueron identificados en la composición de la superficie de los anillos, así como en las muestras 
digeridas. La solución sintética del sudor erosionó la superficie de los anillos tratados y fue observada que los metales tales como Cd y Mn fueron lixiviados. Los resultados indican la presencia y lixiviación de metales tóxicos que pueden causar problemas de salud o ambientales.

Palabras clave: Metales tóxicos; Bisuterías; Sudor sintético.

\section{Introduction}

The use of costume (or fake) jewelry is widespread among the Brazilian population. According to Instituto Brasileiro de Gemas e Metais Preciosos, its market profited R\$ 1.5 billion in 2015 (IBGM, 2015). An expressive share of this market accounts for imported costume jewelry, mostly from China, which is the World's biggest exporter (MME, 2017 ; SEBRAE, 2017). Its fundamental trait of being cheap is, also, its burden. The pressure to create cheaper products results on the overlooking of safety and quality standards (Weidenhamer \& Clement, 2007). The resulting combination of materials includes cheap metals, such as iron or nickel, and sometimes even heavy metal alloys containing cadmium and lead, superficially treated to simulate noble metals (Weidenhamer \& Clement, 2007; Guney \& Zagury, 2013; Guney \& Zagury, 2014). In the scientific literature several works from different countries have already identified the hazardous of toxic metals exposure due to costume jewelries (Moitra, Brashier \& Sahu, 2014; Murphy et al., 2016; Adie, Oyebade \& Atanda, 2020). As in the ancient Trojan horse myth, the shiny surface of a ring might be just a decoy for hazardous substances ready to attack the person wearing it and the environment.

In contact with sweat, costume jewelry tends to oxidize, releasing its surface metals over the skin, causing intoxications, inflammation and bioaccumulation (Basketter et al., 1993; Guney \& Zagury, 2014; Finch, Hillyer \& Leopold, 2015). USA and Canada have regulations and norms that ensures the safety of the costume jewelry, using methods like synthetic sweat tests and metals maximum weight percentages (Guney \& Zagury, 2012). Brazil has a very simple and recent regulation which aims specifically to cadmium (limit of $0.01 \%$ ) and lead (limit of $0.03 \%$ ) content (INMETRO, 2016).

Once the costume jewelry is no longer desired, it is usually disposed like domestic waste, and due to oxidation and leaching, the metals, including the toxic ones, are released into the environment. The disposal of single units is not significant, however the disposal of large quantities may cause serious contaminations (Manheim, 2009; Casemiro, 2015). Considering that the latest report of the syndicate of urban cleaning companies (SELUR) in 2014, more than 40\% of Brazilian waste is disposed incorrectly (SELUR, 2017). It is reasonable to assume that a considerable fraction of those pieces of cheap jewelry will be prone to contaminate the soil and the hydric resources with the metals they carry (Manheim, 2009; Rajaganapathy et al., 2011).

Another key point is the lack of effective control on imported goods in Brazilian market (Jornal de Brasília, 2015). So it's necessary to highlight the necessity of regulation and inspection of the costume jewelry traded in Brazil territory. To achieve those goals, the elemental composition of the external and internal surface, and lixiviation by synthetic sweat of costume jewel rings (imported and commercialized in Brazilian territory) were investigated.

\section{Methodology}

All reagents were analytical grade and were acquired through commercial sources. All reagents were utilized without further purification. On the dilution procedures, only ultrapure water was used.

Imported rings from China were obtained through a popular wholesale's website. It was chosen four different type of rings (Figure 1): metal with silver finishing (MS); metal with golden finishing (MG); steel with silver finishing (SS); and steel with golden finishing (SG). Since the SS rings were smaller than the others, 3 of them were used in Synthetic Sweat Lixiviation Test. 
Figure 1 - Costume jewelry rings used: metal with silver finishing (MS); metal with golden finishing (MG); steel with silver finishing (SS); and steel with golden finishing (SG).

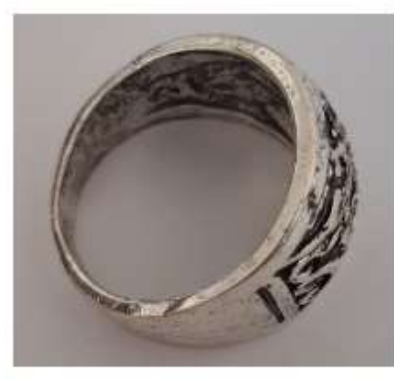

MS

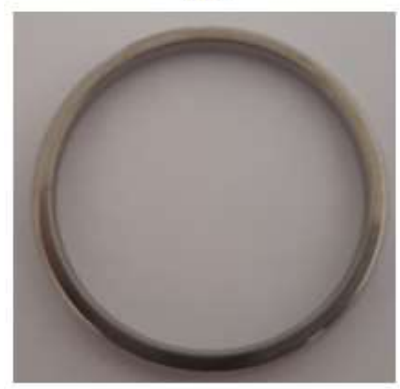

SS

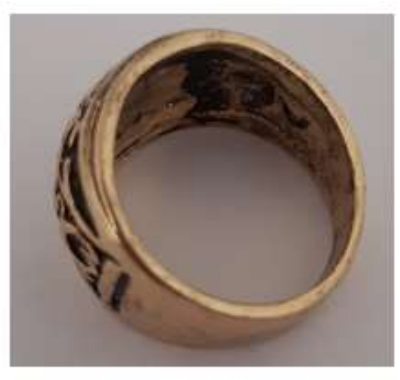

MG

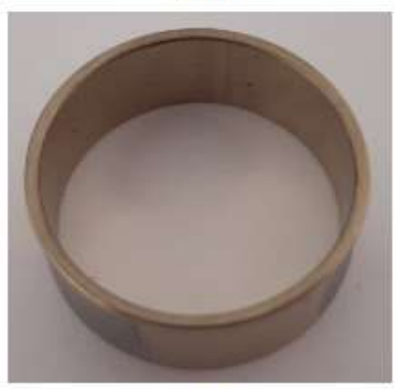

SG

Source: Authors.

The present work is an experimental research of quantitative and qualitative nature (Pereira et al., 2018), where it will be identified and measured the metallic elements present in the samples and their lixiviation patter through synthetic sweat exposure. The Synthetic Sweat Lixiviation Test (SSLT) was conducted following the literature (Colin et al., 1998). The synthetic sweat solution was composed of $\mathrm{NaCl}(0.5 \% \mathrm{~m} / \mathrm{m})$, lactic acid $(0.1 \% \mathrm{~m} / \mathrm{m})$, and urea $(0.1 \% \mathrm{~m} / \mathrm{m})$ dissolved in ultrapure water. Later, the $\mathrm{pH}$ was adjusted to 6.5 with an $\mathrm{NH}_{4} \mathrm{OH}$ solution $(7.1 \mathrm{M})$. Each sample was placed inside test tubes and submerged in the synthetic sweat solution. The volume of solution added on each test tube changed based on the superficial area of the sample, to achieve an immersion parameter of $0.82 \times 10^{-2} \mathrm{~m}$. The test tubes were then covered with plastic film and the rings rested in the solution for 30 days. The temperature was maintained at $36{ }^{\circ} \mathrm{C}$ using a heating plate. After 30 days, the synthetic sweat solutions were filtered and diluted to $50 \mathrm{~mL}$ before the analyses. The rings were washed with ultrapure water and dried for further analysis.

For the sample digestion, a modified method of acid digestion was used, aiming the use to ICP-OES technic

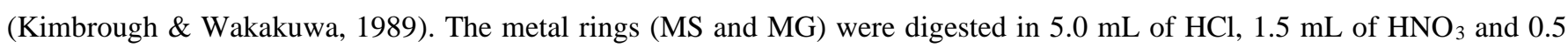
$\mathrm{mL}$ of $\mathrm{H}_{2} \mathrm{O}_{2} 30 \%$ for each $1 \mathrm{~g}$ of sample. On the steel rings ( $\mathrm{SS}$ and $\mathrm{SG}$ ) were used the same solution and the same volumes for each $0.5 \mathrm{~g}$ of sample. The acidic solutions containing the digested samples were filtered and diluted to $100 \mathrm{~mL}$ before being analyzed.

The XRF analysis was conducted using an EDX-720 from Shimadzu, under vacuum and using a 10 mm collimator. The samples were analyzed prior and post the SSLT. The objective of the pre-SSLT sample analysis was to determinate the initial composition of the surface. The data was compared to the post-SSLT sample surface composition to establish whether there occurred corrosion in the ring's surfaces. The SEM analysis was conducted using a JEOL JSM 7199F with FieldEmission Gun (FEG) using an enhancement of 400x. The images were achieved before and after the SSLT to observe the corrosion in the surface after the SSLT. 
The ICP-OES was conducted using a Thermo Fisher Scientific iCAP 6000 Series. Standard solutions were used to build calibration curves for several elements more likely to be found ( $\mathrm{Al}, \mathrm{B}, \mathrm{Ba}, \mathrm{Ca}, \mathrm{Cd}, \mathrm{Co}, \mathrm{Cr}, \mathrm{Cu}, \mathrm{Fe}, \mathrm{K}, \mathrm{Mg}, \mathrm{Mn}, \mathrm{Na}, \mathrm{Ni}$, $\mathrm{Pb}, \mathrm{S}, \mathrm{Si}, \mathrm{Sn}, \mathrm{Ti}$ and $\mathrm{Zn})$. The parameters of the calibration curves are shown in Table 1.

Table 1 - Parameters for ICP-OES multi elemental analysis. Values relative to calibration curves for each element.

\begin{tabular}{|c|c|c|}
\hline Element & Wavelength (nm) & $\mathrm{R}^{2}$ \\
\hline $\mathrm{Al}$ & 167.0 & 0.999385 \\
\hline $\mathrm{B}$ & 249.7 & 0.998556 \\
\hline $\mathrm{Ba}$ & 493.4 & 0.997735 \\
\hline $\mathrm{Ca}$ & 396.8 & 0.927649 \\
\hline $\mathrm{Cd}$ & 214.4 & 0.999802 \\
\hline $\mathrm{Co}$ & 228.6 & 0.999834 \\
\hline $\mathrm{Cr}$ & 359.3 & 0.999843 \\
\hline $\mathrm{Cu}$ & 219.9 & 0.999478 \\
\hline $\mathrm{Fe}$ & 259.9 & 0.996064 \\
\hline $\mathrm{K}$ & 766.4 & 0.995565 \\
\hline $\mathrm{Mg}$ & 280.2 & 0.999631 \\
\hline $\mathrm{Mn}$ & 260.5 & 0.999955 \\
\hline $\mathrm{Na}$ & 589.5 & 0.954259 \\
\hline $\mathrm{Ni}$ & 231.6 & 0.999345 \\
\hline $\mathrm{Pb}$ & 220.3 & 0.998604 \\
\hline$S$ & 182.0 & 0.999545 \\
\hline $\mathrm{Si}$ & 212.4 & 0.935998 \\
\hline Sn & 242.9 & 0.999950 \\
\hline $\mathrm{Ti}$ & 337.2 & 0.999958 \\
\hline $\mathrm{Zn}$ & 213.8 & 0.998899 \\
\hline
\end{tabular}

Source: Authors.

\section{Results and Discussion}

\subsection{Synthetic Sweat Lixiviation Test (SSLT)}

All samples showed macroscopic differences after a month when submerged in the synthetic sweat solution, which can be seen on Figure 2. The steel samples changed the solution aspect; a light, cloudy aspect for SS sample; and a strong rusty color for SG sample. Both samples also contained small flakes. The metal samples formed a white crust on their surfaces. 
Figure 2 - Samples after thirty days of the SSLT.

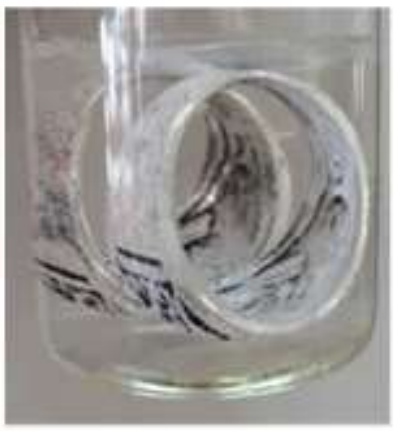

MS

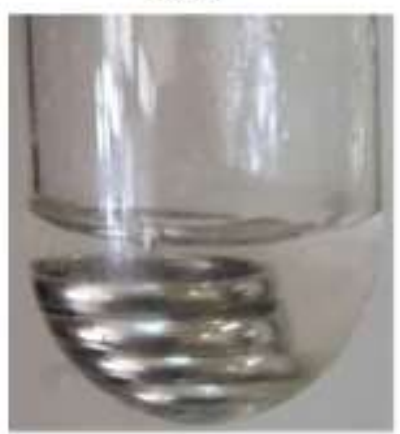

SS

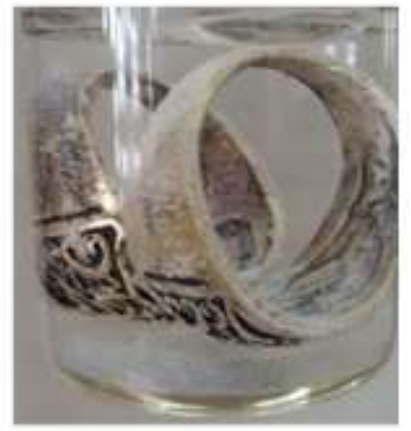

MG

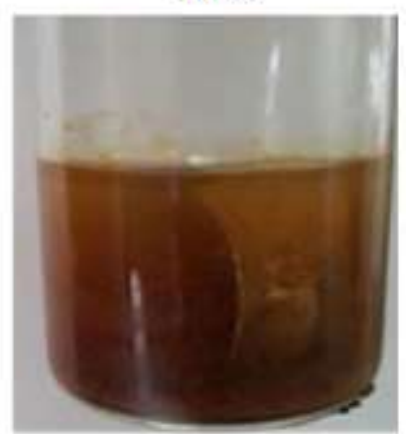

SG

Source: Authors.

The SEM pictures from the surface of the samples showed the corrosion of the samples in SSLT, as depicted in Figure 3. The synthetic sweat solution was able to cause fissures on the surface of the steel samples but unable to promote the same effect in metal samples, in which it appears that a layer was removed. Note that all rings surface was modified by the SSLT. In normal conditions, friction as well could increase the weariness on the rings surface, causing the lixiviation of small particles as well metal cations to skin. 
Figure 3 - SEM from the surface of the samples before (a) and after (b) the SSLT.

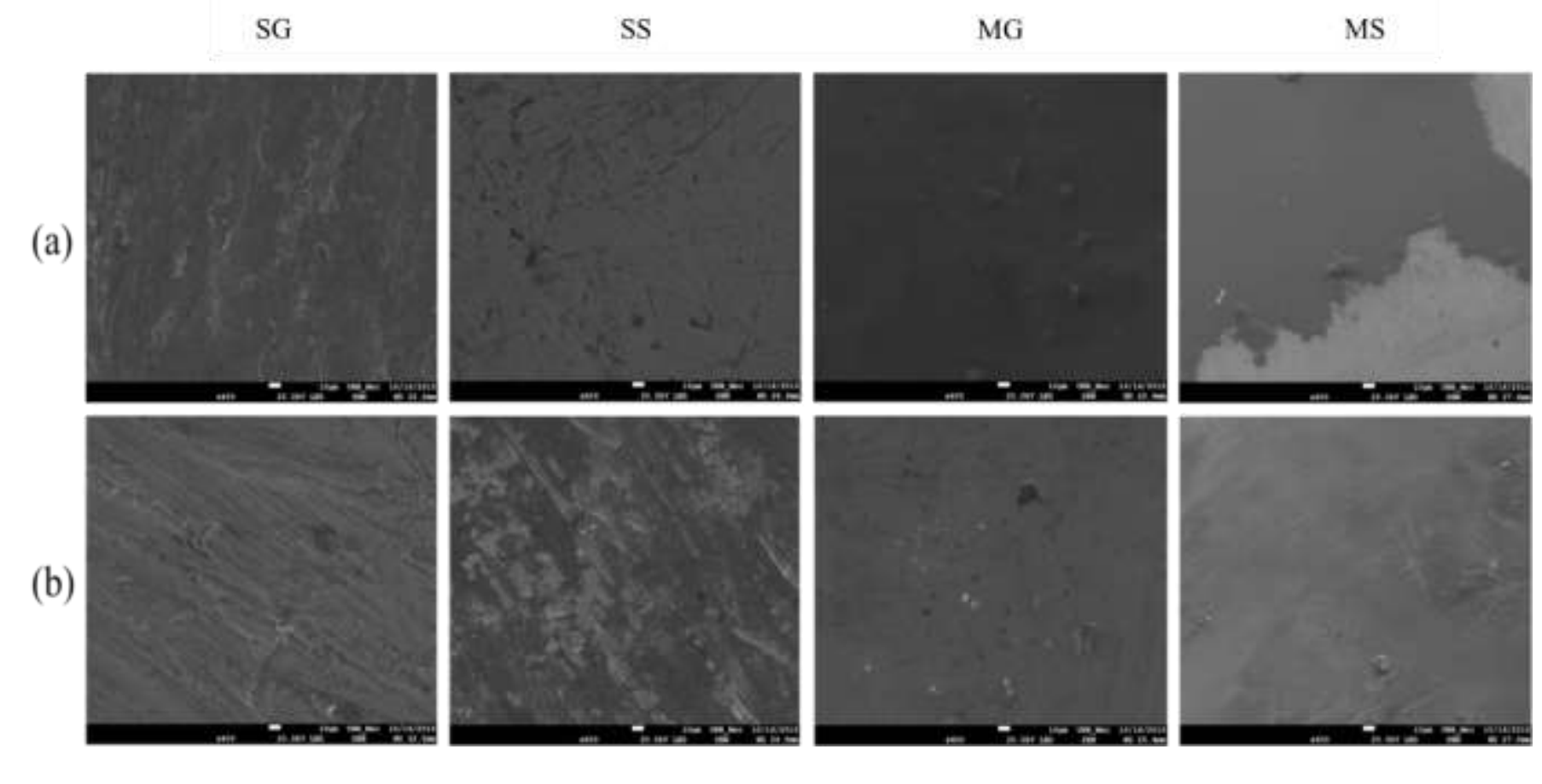

Source: Authors.

The XRF data in Table 2, from the ring samples before and after SSLT, points that the surface composition of the samples is not straight related to the surface finishing performed on the rings. The surface of both the golden finishing and the silver finishing samples differs slightly between steel and metal rings. Despite the appearance of the metal rings, the surface compositions of both samples are similar.

The surface of the metal rings is mostly composed of Copper-Cadmium alloy. Those alloys are very common in the manufacturing of wires, since Cadmium improves Copper properties with lesser interference in the conductivity. However, the Cadmium content seems very high, considering that the usual content is about 1.0\% (Smith, 1919). The steel rings have different surface compositions. The SG sample surface composition is like steel, being mostly composed of $\mathrm{Fe}, \mathrm{Cr}$ and $\mathrm{Mn}$. The SS sample surface composition seems to be based on aluminosilicates, since their most abundant elements are Silicon and Aluminum.

The surface composition of the steel samples after the SSLT is very similar, being basically aluminosilicates. According to Table 2, after the SSLT, the SG sample surface presented a major loss of $\mathrm{Fe}, \mathrm{Cr}$ and $\mathrm{Mn}$, which can be noted also on Figure 2 and Figure 3. That behavior is attributed to flaws in the ring surface which wasn't totally covered by the finishing. Iron is known to react into flaky and porous oxides that do not passivate the surface of the metal. Even though Chromium oxides have passivating properties, it is possible that Chromium oxides, being a small fraction of the surface, have been carried with the iron oxides. The SS sample was less damaged during the SSLT, with no significant variations between elements. A small loss of silicates was noticed on the SS surface, possibly as sodium silicates, which explains the corrosion observed in Figure 3.

According to Table 2, the metal samples maintained their original surface composition, with minor variations throughout the SSLT. These small changes in the composition before and after the SSLT suggests that the corrosion occurs by layer removal, as can be seen on Figure 3. Instead of the grooves observed in the steel samples, the surfaces are relatively flat. Metal samples have also presented a white solid covering its surface after SSLT (Figure 2). This white crust may be composed of oxides, possible $\mathrm{ZnO}$ and $\mathrm{MgO}$, respectively to $\mathrm{MG}$ and MS samples, since those metals were present on the surface 
composition of the samples before SSLT and were absent after the test. These other metals could only be encountered inside the ring since they are more susceptible to oxidation. So, it is expected that those rings would continue to deshell since, since their internal structure appears to be more reactive than their shell. It is worth to mention that MS sample showed in its surface composition a little amount of silver.

Table 2 - Comparison between the surface compositions of the rings before and after SSLT.

\begin{tabular}{|c|c|c|c|c|c|c|c|}
\hline \multicolumn{4}{|c|}{ SG } & \multicolumn{4}{|c|}{ MG } \\
\hline \multicolumn{2}{|c|}{ Before SSLT } & \multicolumn{2}{|c|}{ After SSLT } & \multicolumn{2}{|c|}{ Before SSLT } & \multicolumn{2}{|c|}{ After SSLT } \\
\hline Element & $\%(\mathrm{~m} / \mathrm{m})$ & Element & $\%(\mathrm{~m} / \mathrm{m})$ & Element & $\%(\mathrm{~m} / \mathrm{m})$ & Element & $\%(\mathrm{~m} / \mathrm{m})$ \\
\hline $\mathrm{Fe}$ & 66.5 & $\mathrm{Si}$ & 41.3 & $\mathrm{Cu}$ & 81.9 & $\mathrm{Cu}$ & 74.8 \\
\hline $\mathrm{Cr}$ & 13.6 & $\mathrm{Al}$ & 32.0 & $\mathrm{Cd}$ & 17.1 & $\mathrm{Cd}$ & 16.7 \\
\hline $\mathrm{Mn}$ & 8.8 & $S$ & 11.0 & $\mathrm{Si}$ & 0.3 & $\mathrm{Zn}$ & 8.3 \\
\hline $\mathrm{Al}$ & 2.8 & $\mathrm{~K}$ & 6.3 & $\mathrm{Al}$ & 0.3 & $\mathrm{Si}$ & 0.1 \\
\hline $\mathrm{Ni}$ & 2.0 & $\mathrm{Fe}$ & 6.2 & $\mathrm{Ca}$ & 0.2 & $\mathrm{~S}$ & 0.1 \\
\hline Other & 4.2 & Other & 3.2 & Other & 0.1 & Other & 0.1 \\
\hline \multicolumn{4}{|c|}{ SS } & \multicolumn{4}{|c|}{ MS } \\
\hline \multicolumn{2}{|c|}{ Before SSLT } & \multicolumn{2}{|c|}{ After SSLT } & \multicolumn{2}{|c|}{ Before SSLT } & \multicolumn{2}{|c|}{ After SSLT } \\
\hline Element & $\%(\mathrm{~m} / \mathrm{m})$ & Element & $\%(\mathrm{~m} / \mathrm{m})$ & Element & $\%(\mathrm{~m} / \mathrm{m})$ & Element & $\%(\mathrm{~m} / \mathrm{m})$ \\
\hline $\mathrm{Si}$ & 47.8 & $\mathrm{Si}$ & 38.3 & $\mathrm{Cu}$ & 84.0 & $\mathrm{Cu}$ & 74.6 \\
\hline $\mathrm{Al}$ & 36.3 & $\mathrm{Al}$ & 35.0 & $\mathrm{Cd}$ & 12.8 & $\mathrm{Cd}$ & 14.6 \\
\hline$S$ & 9.5 & $S$ & 14.8 & $\mathrm{Ag}$ & 1.9 & $\mathrm{Mg}$ & 8.6 \\
\hline $\mathrm{K}$ & 3.1 & $\mathrm{~K}$ & 9.1 & $\mathrm{Al}$ & 0.6 & $\mathrm{Ag}$ & 0.6 \\
\hline $\mathrm{Fe}$ & 2.4 & $\mathrm{Fe}$ & 2.1 & $\mathrm{Si}$ & 0.4 & $\mathrm{Si}$ & 0.1 \\
\hline Other & 0.8 & Other & 0.9 & Other & 0.1 & Other & 1.4 \\
\hline
\end{tabular}

Source: Authors.

\subsection{ICP-OES analysis of the synthetic sweat solution post SSLT}

The XRF data, suggests that there is lixiviation of metals from the surface of the rings, so the synthetic sweat solutions used in the SSLT were analyzed by ICP-OES after the test, and the metals that have surpassed $1 \mathrm{mg} . \mathrm{L}^{-1}$ (ppm) in any samples were reported in Table 3. 
Table 3 - Components of the synthetic sweat solutions used in SSLT after 30 days with concentrations higher than 1 mg. $\mathrm{L}^{-1}$.

Concentration $\left(\mathrm{mg} . \mathrm{L}^{-1}\right)$

\begin{tabular}{c|c|c|c|c|c}
\hline Sample: & $\mathrm{Cd}$ & $\mathrm{Zn}$ & $\mathrm{K}$ & $\mathrm{Ca}$ & $\mathrm{Mn}$ \\
\hline $\mathrm{MG}$ & 7.96 & 6.11 & 5.97 & 1.80 & 0.08 \\
\hline $\mathrm{MS}$ & 0.14 & 0.13 & 5.83 & 0.93 & 0.00 \\
\hline SG & 0.25 & 0.25 & 5.07 & 1.82 & 23.57 \\
\hline SS & 0.03 & 0.08 & 2.85 & 0.96 & 0.05 \\
\hline
\end{tabular}

Source: Authors.

It is possible to observe that, despite that almost all the Fe and $\mathrm{Cr}$ from the surface of the SG sample have been removed in the SSLT, the amount of both metals found dissolved in the solution is under 1 ppm. These metals must have formed insoluble compounds during their lixiviation, or lixiviated in small particles from the surface, which can be related to the flakes observed after the SSLT. The presence of Ca and principally K suggests that they are susceptible to lixiviation, so their presence in solution can be related to the corrosion of the rings, due to their major lability and solubility. The same behavior may be expected from sodium, although it could not be analyzed since SSLT solution already contain sodium, which surpasses the detection limit of the equipment. It is worth to highlight that the golden finishing samples presented an elevated concentration of metals such as $\mathrm{Cd}, \mathrm{Zn}$ and $\mathrm{Mn}$.

\subsection{ICP-OES analysis of digested samples}

In Table 4 the content of toxic metals which were detected with significative concentration on the digested ring samples analysis are showed. The presence or $\mathrm{Cr}$ and $\mathrm{Ni}$ were detected in the steel rings samples. The metal rings samples showed the presence of $\mathrm{Cd}$ around $1 \%(\mathrm{~m} / \mathrm{m})$ as expected, confirming the hypothesis that the raw material used is CopperCadmium alloy.

Table 4 - Metal content of the rings obtained by ICP-OES of the digested samples post SSLT.

Metal content\% $(\mathrm{m} / \mathrm{m})$

\begin{tabular}{c|c|c|c}
\hline Sample & $\mathrm{Cd}$ & $\mathrm{Cr}$ & $\mathrm{Ni}$ \\
\hline $\mathrm{MG}$ & 1.18 & $<0.01$ & $<0.01$ \\
\hline $\mathrm{MS}$ & 0.92 & $<0.01$ & $<0.01$ \\
\hline $\mathrm{SG}$ & $<0.01$ & 0.38 & 0.30 \\
\hline $\mathrm{SS}$ & $<0.01$ & 2.49 & 1.29 \\
\hline
\end{tabular}

Source: Authors. 
It is important to highlight that Brazilian regulation permits $0.01 \%$ of $\mathrm{Cd}$ and $0.03 \%$ of $\mathrm{Pb}$ in weight in costume jewelry. In that case, the analyzed metal rings samples do not fit the Brazilian Cd limits. All the samples presented contents of $\mathrm{Pb}$ inferior to $0.01 \%$. Although the steel ring samples don't contain significant amount of $\mathrm{Cd}$ and $\mathrm{Pb}$, it had other unexpected and toxic metals in their composition, including Mn which accounted for $0.21 \%$ of the mass for SS sample and surpassed the detection limit on SG sample.

Those results suggest that that the costume jewelry analyzed in that study were made with low quality materials. The heavy metal identified in the surface, and in the digested samples indicates that those materials used on the fabrication process are not proper for skin contact, and can also, if disposed in large quantities, pose environmental hazard.

\section{Conclusion}

Through the present study of the behavior of different costume jewelry rings when exposed to synthetic sweat, showed that every sample suffers metal loss in different forms, which can be soluble or insoluble in sweat. The weariness of the rings can cause health problems in longtime uses, due to the exposure to toxic metal.

It was identified that the metal rings used in the study doesn't attend to Brazilian regulation due to the presence of $\mathrm{Cd}$ above permitted concentration. Also, the steel rings samples showed in their composition toxic metal such as $\mathrm{Ni}, \mathrm{Cr}$ and $\mathrm{Mn}$. The identification of these toxic metal draws attention to the risk of environmental hazards due to the incorrect discard of that pieces.

In Brazil, there is a very simple legislation on heavy metal composition in costume jewelry and virtually no inspection on importations of small goods, coming mainly from China, and few studies dedicated to costume jewelry lixiviation. Therefore, the present work exposes this problem, as well as to encourage further works, which could use more samples in the qualitative-quantitative analysis of toxic metals in costume jewelry.

\section{Acknowledgments}

The authors are thankful to CNPq, FAP-DF and CAPES for financial support. The authors wish also to thank to the Laboratório de Materiais e Metalurgia - FT - UnB which granted access to the SEM equipment and the Laboratório de Materiais e Combustíveis - IQ - UnB for the suport in equipment and materials.

\section{References}

Adie, G. U.; Oyebade, E. O. \& Atanda, B. M. (2020). Preliminary Study of Heavy Metals in Low-Cost Jewelry Items Available in Nigerian Markets. Journal of Health \& Pollution, 10 (8), 1-7. https://doi.org/10.5696/2156-9614-10.28.201202

Basketter, D. A.; Briatico-Vangosa, G.; Kaestner, W.; Lally, C. \& Bontinck, W. J. (1993). Nickel, cobalt and chromium in consumer products: a role in allergic contact dermatitis? Contact Dermatitis, 28(1), 15-25. https://doi.org/10.1111/j.1600-0536.1993.tb03318.x

Casemiro, L. (2015). Bijuterias têm até 60 vezes mais cádmio e chumbo do que o aceito nos EUA. https://oglobo.globo.com/economia/defesa-doconsumidor/bijuterias-tem-ate-60-vezes-mais-cadmio-chumbo-do-que-aceito-nos-eua-15328212

Colin, S.; Krier, G.; Jolibois, H.; Hachimi, A.; Muller, J. F. \& Chambaudet, A. (1998). Characterization of the corrosion layer of copper-nickel alloys in a synthetic sweat medium by FTMS and LAMMA laser microprobes. Applied Surface Science, 125 (1), 29-45. https://doi.org/10.1016/s0169-4332(97)00400-5

Finch, L. E.; Hillyer, M. M. \& Leopold, M. C (2015). Quantitative Analysis of Heavy Metals in Children's Toys and Jewelry: A Multi-Instrument, Multitechnique Exercise in Analytical Chemistry and Public Health. Journal of Chemical Education, 92 (5), 849-854. https://doi.org/10.1021/ed500647w

Guney, M. \& Zagury, G. J. (2012). Heavy Metals in Toys and Low-Cost Jewelry: Critical Review of U.S. and Canadian Legislations and Recommendations for Testing. Environmental Science \& Technology, 46 (8), 4265-4274. https://doi.org/10.1021/es203470x

Guney, M. \& Zagury, G. J. (2013). Contamination by Ten Harmful Elements in Toys and Children's Jewelry Bought on the North American Market. Environmental Science \& Technology, 47 (11), 5921-5930. https://doi.org/10.1021/es304969n

Guney, M. \& Zagury, G. J. (2014). Bioaccessibility of As, Cd, Cu, Ni, Pb, and Sb in Toys and Low-Cost Jewelry. Environmental Science \& Technology, 48 (2), 1238-1246. https://doi.org/10.1021/es4036122 
Research, Society and Development, v. 10, n. 11, e291101119750, 2021

(CC BY 4.0) | ISSN 2525-3409 | DOI: http://dx.doi.org/10.33448/rsd-v10i11.19750

IBGM - Instituto Brasileiro de Gemas e Metais Preciosos (2015). O setor em Grandes Números 2015. https://ibgm.com.br/publicacao/o-setor-em-grandesnumeros-2015/

INMETRO - Instituto Nacional de Metrologia, Qualidade e Tecnologia (2016). Portaria $N^{o}$ 43, de 22 de janeiro de 2016, DOU 26.01.2016. BR. https://www.anamt.org.br/portal/2016/03/02/portaria-inmetro-no-43-de-22-de-janeiro-de-2016/

Jornal de Brasília (2015). Receita admite “dificuldades grandes” em fiscalizar remessas postais. https://www.jornaldebrasilia.com.br/economia/receita-admitedificuldades-grandes-em-fiscalizar-remessas-postais/

Kimbrough, D. E. \& Wakakuwa, J. R. (1989). Acid digestion for sediments, sludges, soils, and solid wastes. A proposed alternative to EPA SW 846 Method 3050. Environmental Science \& Technology, 23 (7), 898-900. https://doi.org/10.1021/es00065a021

Manheim, J. (2009). Sustainable jewellery, $1^{\text {st }}$ ed.. London, UK: A\&C Black.

MME - Ministério de Minas e Energia (2017). Anuário estatístico do setor de transformação de não metálicos. http://www.mme.gov.br/web/guest/secretarias/geologia-mineracao-e-transformacao-mineral/publicacoes/anuario-estatistico-do-setor-metalurgico-e-do-setorde-transformacao-de-nao-metalicos

Moitra, S.; Brashier, B. B. \& Sahu, S. (2014). Occupational cadmium exposure-associated oxidative stress and erythrocyte fragility among jewelry workers in India. American Journal of Industrial Medicine, 57 (9), 1064-1072. https://doi.org/10.1002/ajim.22336

Murphy, T.; Lim, S.; Kim, S.; Irvine, K.; Chaiwat, W. \& Wilson, K. (2016). Metal Contamination in Low-Cost Jewelry and Toys in Cambodia. Journal of Health and Pollution, 6 (11), 47-57. https://doi.org/10.5696/2156-9614-6-11.47

Pereira, A. S.; Shitsuka, D. M.; Parreira, F. J. \& Shitsuka, R. (2018). Metodologia da pesquisa científica, $1^{\text {a }}$ ed. Santa Maria, RS: UFSM,NTE. https://repositorio.ufsm.br/bitstream/handle/1/15824/Lic_Computacao_Metodologia-Pesquisa-Cientifica.pdf?sequence=1

Rajaganapathy, V.; Xavier, F.; Sreekumar, D. \& Mandal, P. K. (2011). Heavy Metal Contamination in Soil, Water and Fodder and their Presence in Livestock and Products : A Review. Journal of Environmental Science and Technology, 4 (3), 234-249. https://doi.org/10.3923/jest.2011.234.249

SEBRAE - Serviço Brasileiro de Apoio Às Micro e Pequenas Empresas (2017). Estudo Setorial de Joias e Semi Joias, Bijuterias e Ótica de Santa Catarina. www.bibliotecas.sebrae.com.br/chronus/ARQUIVOS_CHRONUS/bds/bds.nsf/df3e055f846d37170c9060e76faaa9c0/\$File/5745.pdf

SELUR - Sindicato das Empresas de Limpeza Urbana (2017). Índice de Sustentabilidade da Limpeza Urbana para os municípios brasileiros. www.selur.org.br/wp-content/uploads/2017/08/ISLU_2EDICAO_2017.pdf

Smith, W. C. (1919). US pat. 1307642. https://www.patents.google.com/patent/US1307642A/en

Weidenhamer, J. D. \& Clement, M. L. (2007). Leaded electronic waste is a possible source material for lead-contaminated jewelry. Chemosphere, 69 (7), 1111-1115. https://doi.org/10.1016/j.chemosphere.2007.04.023 